\title{
PENGGUNAAN FACEBOOK SEBAGAI MEDIA INOVATIF DALAM PEMBELAJARAN SMP DAN SMA DI PERGURUAN MUHAMMADIYAH WIYUNG SURABAYA
}

\author{
Oleh: \\ Rudy Kustijono ${ }^{1}$, Titin Sunarti2, Hermin Budiningarti ${ }^{3}$ \\ 1,2,3 Jurusan Fisika FMIPA Unesa \\ 'rudykustijono@unesa.ac.id
}

\begin{abstract}
Abstrak
Telah dilakukan kegiatan pengabdian kepada masyarakat di Perguruan Muhammadiyah Wiyung Surabaya. Tujuan pengabdian adalah: 1) meningkatkan pemahaman guru SMP dan SMA terhadap penggunaan facebook sebagai media pembelajaran inovatif, 2) mendorong guru menerapkan media pembelajaran inovatif menggunakan facebook, 3) penggunaan media pembelajaran inovatif menggunakan facebook mendapatkan respon yang baik dari siswa. Metode kegiatan adalah pelatihan, pendampingan, penerapan, dan penilaian. Teknik pengambilan data adalah pengamatan dan angket. Skor angket menggunakan skala Likert (skala 1-4), dan kategori skor rerata adalah: sangat kurang $(1 \leq x<1,5)$, kurang $(1,5 \leq x<2,5)$, baik $(2,5 \leq x<3,5)$, dan sangat baik $(3,5 \leq x \leq 4)$. Analisis data untuk mengukur kategori keberhasilan dilakukan dengan menghitung rerata skor dan persentase tiap aspek yang ditanyakan. Hasil yang diperoleh dari penggunaan media pembelajaran inovatif menggunakan facebook adalah: 1) pemahaman guru meningkat, 2) $30 \%$ guru membuat grup facebook dan menerapkannya dalam pembelajaran, 3) mendapatkan respon yang baik dari guru dan siswa. Kesimpulan yang diperoleh adalah kegiatan pelatihan, pendampingan, penerapan, dan penilaian penggunaan facebook sebagai media pembelajaran inovatif menghasilkan peningkatan pemahaman guru, menghasilkan media pembelajarn inovatif karya guru, dan mendapatkan respon yang baik dari siswa.
\end{abstract}

Kata Kunci: facebook, media pembelajaran inovatif

\begin{abstract}
A community service has been conducted at Perguruan Muhammadiyah Wiyung Surabaya. The objectives are: 1) improve the understanding of junior and senior high school teachers on the use of facebook as an innovative learning media, 2) encourage teachers to apply innovative learning media using facebook, 3) Getting a good response from students to use Facebook as innovative media in learning. Methods of activity are training, mentoring, implementation, and evaluation. Technique of taking data is observation and questionnaire. The questionnaire scores use the Likert scale (scale 1-4), and the average score category is: very less $(1 \leq x<1.5)$, less $(1.5 \leq x<2.5)$, good $(2.5 \leq x<3.5)$, and very good $(3.5 \leq x \leq 4)$. Data analysis to measure success categories is done by calculating the mean score and percentage of each aspect in question. The results obtained from the use of innovative learning media using facebook are: 1) teacher understanding increases, 2) 30\% teachers create facebook group and apply it in learning, 3) get good response from teachers and students. The conclusion is that training, mentoring, implementation, and evaluating of facebook usage as an innovative learning media resulted in improving teachers' understanding, producing innovative learning media by teachers, and getting good responses from students.
\end{abstract}

Keywords: facebook, innovative learning media

\section{PENDAHULUAN}

Secara umum penguasaan guru terhadap TIK masih rendah, namun motivasi untuk dapat memanfaatkannya dalam pembelajaran cukup tinggi (Siswanto, 2012). Multimedia pembelajaran adalah segala sesuatu yang digunakan untuk menyalurkan pesan (pengetahuan, keterampilan, dan sikap), serta dapat merangsang pikiran, perasaan, perhatian dan kemauan sehingga secara sengaja proses belajar terjadi, bertujuan, dan terkendali (Hartono, 2004). Ada enam komponen media yang dapat dikategorikan 
multimedia pembelajaran, yaitu: teks, grafik, foto, video, suara, animasi/simulasi. Multimedia berperan semakin penting dalam pembelajaran. karena dapat membawa kepada situasi belajar dimana "learning with effort" digantikan dengan "learning witf fun" (Nurtjahjawilasa, 2004). Proses pembelajaran yang menyenangkan, kreatif, tidak membosankan menjadi pilihan para fasilitator. Level-level multimedia adalah: 1) Teknis (alat-alat teknis); 2) Semiotik (representasi hasil seperti teks, gambar, grafik, tabel, dll); 3) Sensorik (saluran sensorik yang berfungsi untuk menerima tanda/sign (Mayer, 2001). Memanfaatkan ketiga level di atas diharapkan dapat mengoptimalkan dan mengefektifkan pemanfaatan multimedia dalam proses pembelajaran. Jenis multimedia pembelajaran meliputi: 1) Presentasi (menjelaskan materi-materi yang sifatnya teoritis, digunakan dalam pembelajaran klasikal dengan kelompok belajar yang cukup besar); 2) Interaktif (bersifat interaktif dan multimedia). (Rusman, 2012) dan (Samsudin, 2012). Meskipun banyak kelebihan yang diperoleh, namun terdapat beberapa tantangan yang muncul akibat penerapan teknologi informasi dan komunikasi dalam bidang pembelajaran yaitu (Payong, 2012): 1) orientasi filisofis, 2) lingkungan belajar sibermetik, 3) kontrol siswa atas pembelajarannya, 4) bentuk umpan balik yang sesuai, dan 5) sifat sosial yang dapat dibangun.

Facebook adalah situs jejaring sosial yang dibuat Mark Zuckerberg telah menjadi virus yang mewabah jutaan manusia di seluruh dunia. facebook mempunyai anggota lebih dari 500 juta pengguna pada tahun 2011 yang tentunya sekarang menjadi jauh lebih besar lagi. Rata-rata 700 miliar menit dihabiskan di situs jejaring sosial ini per bulan (Facebook, 2011). Pengguna facebook di Indonesia adalah dari semua kalangan dan sebagian besarnya kalangan remaja. Kemudahan yang didapatkan di facebook menjadi daya tarik tersendiri bagi para remaja, sehingga sebagian besar mereka memiliki akun facebook. Di era global saat ini, penggunaan facebook dalam pembelajaran adalah keniscayaan, meskipun terdapat kelebihan dan kelemahan. Layanan yang ditawarkan facebook sangat lengkap, salah satu kelebihan yang dimiliki adalah dapat digunakan untuk membangun komunitas. Dengan komunitas tersebut, kita dapat sharing dan mencari solusi pemecahan tentang berbagai persoalan dengan sesama anggota komunitas. Sayangnya, penggunaan facebook oleh pelajar/mahasiswa di tanah air sering digunakan untuk sesuatu yang tidak bermanfaat atau hanya sekedar untuk bersenang-senang (just for fun) belaka. Mereka lebih suka memainkan game, kuis yang tidak jelas tujuan dan manfaatnya, atau sekedar chatting dengan topik yang tidak perlu. Kegiatan seperti ini akan banyak membuang waktu dan memboroskan dana saja. Suatu keputusan yang tidak tepat jika kita menyalahkan facebook, karena pada dasarnya teknologi itu bersifat netral. Oleh karena itu, kita perlu mengajak para pelajar/mahasiswa memanfaatkan facebook ini dengan cara yang lebih positif. Penulis memandang, dengan mengembangkan kreativitas, facebook dapat digunakan untuk mendukung proses pembelajaran.

Salah satu fasilitas di facebook yang dapat digunakan dalam pembelajaran adalah pembuatan grup. Melalui grup chat dan multimedia tersebut, memungkinkan anggota grup dapat berbagi pesan, berbagi gambar, dan berbagi video (Bere, 2012). Grup ini dapat digunakan guru untuk memberikan informasi kepada para siswa tentang agenda pembelajaran dan dapat digunakan untuk mengeksplorasi, mengelaborasi, dan mengkonfirmasi suatu topik bahasan. Melalui grup, semua anggota dapat memberikan komentar tentang suatu bahasan sehingga siswa dapat mendiskusikan materi yang sedang dibahas tersebut. Guru atau seorang siswa anggota grup dapat memulai sebuah topik yang akan didiskusikan bersama dengan mengunggah gambar atau video disertai penjelasan materinya, kemudian anggota grup yang lain dapat menambahkan pengetahuan atau pendapatnya tentang topik yang sedang dibahas tersebut. Melalui grup, para siswa dapat mengkritisi pendapat temannya atau menambahkannya dengan pengetahuan yang lebih kaya. Guru dapat memantau dan menengahi diskusi tersebut serta meluruskan jika ada konsep yang menyimpang. Kegiatan tersebut dapat dilakukan kapan saja dan dimana saja, sehingga dapat dilakukan di luar kelas. Beberapa penelitian telah menghasilkan efektivitas penggunaan facebook dalam pembelajaran antara lain: 1) pembelajaran melalui facebook dapat digunakan untuk melatihkan keterampilan proses sains dasar (Kustijono, 2012), 2) pembelajaran melalui facebok dapat digunakan untuk melatihkan keterampilan berpikir kritis (Kustijono, 2013), 
3) pembelajaran melalui facebok dapat digunakan untuk meningkatkan hasil belajar siswa SMP (Ni'am, 2013).

TIK di Perguruan Muhammadiyah Wiyung Surabaya telah digunakan dalam upaya memperluas akses informasi terutama yang berhubungan dengan masalah database sekolah (keuangan, data dan nilai siswa, dII). Dalam bidang pembelajaran, perguruan sedang berupaya menyediakan sarpras yang berbasis multimedia untuk mendukung proses pembelajaran yang maksimal. Kendala yang dihadapi adalah ketersediaaan nara sumber yang dapat membantu para guru dalam menerapkan multimedia dalam pembelajaran tersebut. Langkah yang telah dilakukan perguruan atau pihak sekolah dalam mengatasi kendala tersebut adalah memberdayakan guru yang mempunyai kemampuan lebih dalam hal multimedia untuk mengajari guru-guru teman sejawatnya. Langkah yang lain adalah mendatangkan nara sumber ahli untuk mendampingi para guru menerapkan multimedia dalam pembelajaran tersebut. Terkait dengan diperlukannya nara sumber ahli untuk mendamping para guru dalam mengembangkan dan menerapkan multimedia dalam pembelajaran di lembaga mitra, tim PKM dapat memenuhi kebutuhan tersebut. Seorang dosen berkewajiban memenuhi Tri Darma Pendidikan Tinggi yaitu: pendidikan, penelitian, dan pengabdian kepada masyarakat. Situasi tersebut menjadi saling menguntungkan ke dua belah pihak antara tim PKM dan lembaga mitra, karena lembaga mitra membutuhkan nara sumber ahli, sementara itu tim PKM membutuhkan tempat untuk melaksanakan kegiatan pengabdian kepada masyarakat sebagai salah satu darma yang harus dilaksanakan oleh dosen.

SMP Muhammadiyah 17 Surabaya dan SMA Muhammadiyah 9 Surabaya adalah sekolah-sekolah di bawah Perguruan Muhammadiyah Wiyung Surabaya keduanya memiliki visi yang berbasis multimedia. Karena multimedia di sekolah tersebut harus terintegrasi dan selalu digunakan dalam pembelajaran, tentu akan menjadi kendala yang meresahkan jika para guru kurang menguasai penggunaan multimedia dalam pembelajaran tersebut. Oleh karena itu, sekolah-sekolah tersebut dipilih sebagai mitra dalam pelaksanaan PKM. Mencermati kelebihan fitur-fitur yang disediakan facebook dan mencermati karakteristik pembelajaran, penulis memandang bahwa pembelajaran melalui facebook dapat diterapkan di sekolah menengah untuk memberdayakan facebook dan mengurangi dampak negatifnya bagi siswa. Untuk itu kegiatan PKM diarahkan pada penggunaan facebook sebagai media inovatif dalam pembelajaran di SMP dan SMA. Tujuan yang ingin dicapai dalam kegiatan pengabdian kepada masyarakat (PKM) adalah:

1. Meningkatkan pemahaman guru di lembaga mitra terhadap penggunaan facebook sebagai media inovatif dalam pembelajaran.

2. Menghasilkan media inovatif yang menggunakan facebook karya guru di lembaga mitra dan menerapkannya dalam pembelajaran.

Penggunaan facebook sebagai media inovatif dalam pembelajaran mendapatkan respon baik dari siswa.

\section{METODE PELAKSANAAN}

Dari berbagai metode kegiatan yang dapat dipilih, dengan memperhatikan berbagai pertimbangan tim pengabdian kepada masyarakat memilih metode kegiatan pelatihan (training), pendampingan (mentoring), penerapan (implementation), dan penilaian (evaluation). Prosedur kegiatan yang dilakukan adalah sebagai berikut:

1. Mereview wawasan para guru terkait penggunaan facebook sebagai media inovatif dalam pembelajaran dan memberikan penguatan terhadap wawasan yang telah dimiliki. Pemetaan dilakukan dengan memberikan angket kepada guru sebelum pelatihan dilaksanakan.

2. Melatih para guru menggunakan facebook sebagai media inovatif dalam pembelajaran dan memberikan penguatan bagi para guru yang telah memiliki kemampuan tersebut. Pelatihan dititik beratkan pada pemanfaatan grup pada facebook untuk membangun komunitas belajar terutama untuk membangun interaksi belajar antara guru-siswa dan siswa-siswa melalui pesan teks, gambar, dan video.

3. Mendampingi para guru menggunakan facebook sebagai media inovatif dan penerapannya dalam pembelajaran. Pendampingan dititik beratkan pada penerapan facebook sebagai media inovatif dalam pembelajaran, dan bagaimana cara menentukan tujuan 
pembelajaran yang sesuai dan mengintegrasikannya dengan RPP.

4. Memantau para guru di Perguruan Muhammadiyah Wiyung Surabaya dalam menerapkan penggunaan facebook sebagai media inovatif dan perangkat pembelajarannya di kelas.

5. Melakukan penilaian dengan memberi angket pada para guru terkait dampak yang diperoleh dan memantau respon siswa terhadap penggunaan facebook sebagai media inovatif dalam pembelajaran di kelas melalui grup pembelajaran yang telah dibuat.

Teknik pengambilan data yang digunakan adalah pengamatan (difokuskan pada penerapan media inovatif menggunakan facebook dalam pembelajaran) dan angket (difokuskan pada bagaimana dampak yang diperoleh dari penggunaan media tersebut). Aspek-aspek yang ditanyakan dalam angket meliputi aspek teknis dan aspek pembelajaran. Skor angket menggunakan skala Likert (sangat kurang $=1$, kurang $=2$, baik $=3$, dan sangat baik $=4$ ), sedangkan kategori skor rerata adalah: sangat kurang (1 $\leq x<1,5)$, kurang $(1,5 \leq x<2,5)$, baik $(2,5 \leq x$ $<3,5)$, dan sangat baik $(3,5 \leq x \leq 4)$.

Analisis data untuk mengukur kategori keberhasilan dilakukan dengan menghitung rerata skor dan persentase tiap aspek yang ditanyakan. Kegiatan dinyatakan berhasil jika skor rerata yang dipertoleh tiap aspek dalam kategori baik atau sangat baik, atau diperoleh nilai $\geq 61 \%$ dari nilai maksimal.

\section{HASIL DAN PEMBAHASAN}

\section{Pemahaman Guru Terhadap Penggunaan Facebook dalam Pembelajaran}

Pemahaman guru terhadap penggunaan facebook sebagai media pembelajarn inovatif dijaring dengan angket (sampel 20 orang peserta pelatihan) yang diberikan sebalum dan sesudah kegiatan pelatihan dengan hasil seperti Tabel 1 sebagai berikut:

Tabel 1. Pemahaman Guru terhadap Penggunaan Facebook sebagai Media Pembelajaran

\begin{tabular}{|c|c|c|c|c|}
\hline \multirow{2}{*}{ No. } & \multirow{2}{*}{ Aspek yang Dinilai } & \multicolumn{2}{|c|}{ Skor Rerata } & \multirow[t]{2}{*}{ Kategori } \\
\hline & & Sebelum & Sesudah & \\
\hline 1 & $\begin{array}{l}\text { Wawasan tentang pembelajaran inovatif yang } \\
\text { memanfaatkan teknologi informasi dan komunikasi }\end{array}$ & 2,45 & 3,25 & Naik \\
\hline 2 & $\begin{array}{l}\text { Pemahaman tentang pembelajaran menggunakan } \\
\text { facebook sebagai pembelajaran berbasis } \\
\text { multimedia }\end{array}$ & 2,30 & 3,20 & Naik \\
\hline 3 & $\begin{array}{l}\text { Pemahaman tentang facebook yang dimanfaatkan } \\
\text { dalam proses pembelajaran berbagai mapel di } \\
\text { sekolah }\end{array}$ & 2,45 & 3,10 & Naik \\
\hline 4 & $\begin{array}{l}\text { Minat terhadap penggunaan facebook dalam } \\
\text { pembelajaran sesuai mapel yang diampu }\end{array}$ & 2,45 & 2,95 & Naik \\
\hline 5 & $\begin{array}{l}\text { Pemahaman tentang mengekspresikan gagasan } \\
\text { dan pendapat dalam pembelajaran melalui } \\
\text { facebook }\end{array}$ & 2,40 & 2,95 & Naik \\
\hline 6 & $\begin{array}{l}\text { Pemahaman tentang menyajikan gagasan yang } \\
\text { sistematis dalam pembelajaran melalui facebook }\end{array}$ & 2,50 & 3,00 & Naik \\
\hline 7 & $\begin{array}{l}\text { Pemahaman tentang menggunakan bahasa } \\
\text { Indonesia yang baik dalam pembelajaran melalui } \\
\text { facebook }\end{array}$ & 2,90 & 3,00 & Naik \\
\hline 8 & $\begin{array}{l}\text { Pemahaman tentang menampilkan gambar dan } \\
\text { video dalam pembelajaran melalui facebook }\end{array}$ & 2,55 & 3,05 & Naik \\
\hline 9 & $\begin{array}{l}\text { Pengalaman baru penggunaan media } \\
\text { pembelajaran inovatif yang memanfaatkan TIK }\end{array}$ & 2,30 & 3,10 & Naik \\
\hline 10 & $\begin{array}{l}\text { Menjadi satu contoh alternatif penggunaan media } \\
\text { pembelajaran inovatif yang mendorong inovasi } \\
\text { lainnya }\end{array}$ & 2,35 & 3,15 & Naik \\
\hline & Skor rerata total & 22,30 & 27,75 & \\
\hline & Skor rerata maksimal & 40 & 40 & \\
\hline
\end{tabular}

Berdasarkan Tabel 1 didapatkan bahwa pemahaman para guru terhadap penggunaan facebook sebagai media pembelajaran inovatif antara sebelum kegiatan pelatihan 
dan setelah kegiatan pelatihan ada peningkatan yang berarti. Tingkat pemahaman guru sebelum kegiatan adalah $22,3 / 40=56 \%$ atau kategori kurang, sedangkan setelah kegiatan tingkat pemahaman guru adalah $27,75 / 40=69 \% \geq$ $61 \%$ atau kategori baik. Hal tersebut menunjukkan bahwa para guru mempunyai potensi dapat mengembangkan pembelajaran menggunakan facebook, dan dapat memanfaatkannya sebagai satu alternatif variasi pembelajaran.

Secara umum peserta pelatihan berpandangan bahwa penggunaan facebook sudah biasa dilakukan siswa, tetapi guru sendiri sebelum pelatihan belum ada yang menggunakan facebook sebagai media pembelajaran. Berdasarkan pengamatan Tim PKM, penerapan facebook sebagai media pembelajaran oleh para guru masih menemui beberapa kendala, terutama lemahnya inisiatif apalagi kreativitas para guru dalam memanfaatkan potensi yang dimiliki oleh teknologi informasi dan komunikasi khususnya facebook dan media sosial lainnya. Sebagian besar mereka hanya memanfaatkan facebook tersebut sebagai alat bersenang-senang atau setidaknya hanya sebagai alat komunikasi saja. Oleh karena itu para guru SMP dan SMA di Perguruan Muhammadiyah Wiyung Surabaya yang hampir semuanya memiliki akun facebook tersebut belum ada satupun yang memanfaatkannya sebagai media pembelajaran. Sekalipun konten-konten yang mereka unggah ada yang berkaitan dengan kegiatan di sekolah, namun hanyalah berisi promosi atau dokumentasi kegiatan pembelajaran saja. Melalui kegiatan ini mereka menjadi menyadari adanya potensi yang dimiliki facebook untuk kegunaan yang lain khususnya sebagai media pembelajaran. Setelah kegiatan pelatihan, $67 \%$ guru telah mempunyai pemahaman yang baik cara menggunakan facebook sebagai media pembelajaran. Namun demikian, mereka belum sepenuhnya memahami cara merumuskan tujuan pembelajarannya. Hal tersebut dapat dimaklumi karena para guru masih baru dalam penggunaan media dalam pembelajaran tersebut sehingga masih memerlukan pendampingan.

\section{Penerapan Facebook Sebagai Media Pembelajaran Inovatif}

Sebagai satu alternatif variasi pembelajaran, penggunaan facebook cukup menarik para guru untuk menerapkannya dalam kelas. Melalui pendampingan, 30\% guru telah membuat grup facebook dan menerapkannya dalam pembelajaran. Grup facebook pembelajaran tersebut diterapkan untuk beberapa mapel yang ada. Salah satu contoh grup facebook dari guru di Perguruan Muhammadiyah Wiyung yang memanfaatkannya sebagai media pembelajaran mapel tertentu dapat ditampilkan seperti pada Gambar 1. sebagai berikut:



Gambar 1. Contoh Grup Facebook yang Digunakan untuk Media Pembelajaran

di Perguruan Muhammadiyah Wiyung

Contoh konten grup facebook dari guru di Perguruan Muhammadiyah Wiyung yang memanfaatkannya sebagai media pembelajaran mapel tertentu dapat ditampilkan seperti gambar 2 sebagai berikut: 


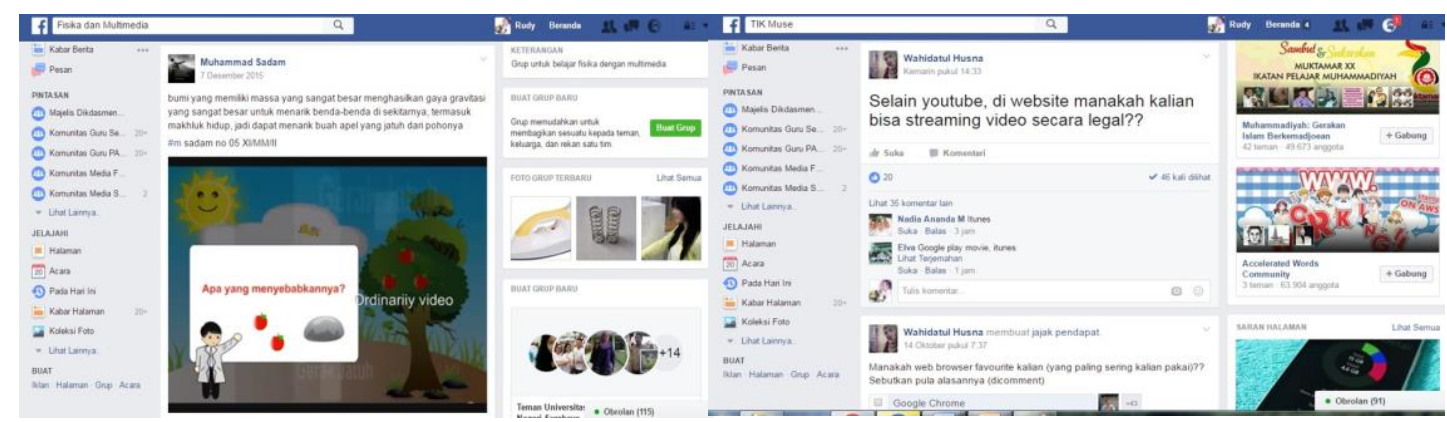

Gambar 2. Contoh Konten Grup Facebook yang Digunakan untuk Media Pembelajaran di Perguruan Muhammadiyah Wiyung

Motivasi para guru dalam membuat media pembelajarn inovatif menggunakan facebook adalah perkembangan yang bagus. Di luar negeri, pemanfaatan facebook dalam pembelajaran sudah biasa dilakukan. Dari hasil survey siswa SMA Ontario $27 \%$ menyatakan bahwa setidaknya satu guru telah menggunakan facebook ke dalam pelajarannya (Fewkes \& McCabe, 2012). Berdasarkan pengamatan dari konten-konten yang diunggah di grup facebook dari guru yang menggunakannya sebagai media pembelajaran, belum semuanya memenuhi harapan dari kegiatan PKM ini. Sebagian sudah terintegrasi dalam RPP yang dipersiapkan, sementara sebagian yang lainnya antara media yang dibuat dengan RPP yang dipersiapkan tersebut belum sinkron. Berdasarkan kondisi tersebut, tampaknya para guru tidak hanya memerlukan pendampingan terkait pembuatan media saja, tetapi perlu juga mendapatkan pendampingan cara pembuatan RPP yang baik. Kegiatan tersebut tampaknya perlu mendapat perhatian untuk ditindaklanjuti.

\section{Respon Siswa Terhadap Penggunaan Facebook Sebagai Media Pembelajaran Inovatif}

Berdasarkan pengamatan pada grup facebook yang digunakan guru untuk pembelajaran terkait aktivitas dan peran serta siswa dalam grup tersebut (sampel 10 grup), dapat diperoleh informasi respon siswa seperti Tabel 2 sebagai berikut:

Tabel 2. Respon Siswa Terkait Penggunaan Facebook sebagai Media Pembelajaran

\begin{tabular}{clcc}
\hline No. & \multicolumn{1}{c}{ Aspek Penilaian } & $\begin{array}{c}\text { Skor } \\
\text { Rerata }\end{array}$ & Kategori \\
\hline 1 & Berperan serta aktif dalam pembelajaran & 3,7 & Sangat Baik \\
\hline 2 & $\begin{array}{l}\text { Memberikan respon positif pada konten yang diunggah } \\
\text { guru }\end{array}$ & 3,6 & Sangat Baik \\
\hline 3 & $\begin{array}{l}\text { Berani menyampaikan gagasan terkait konten yang } \\
\text { diunggah guru }\end{array}$ & 3,8 & Sangat Baik \\
\hline 4 & Meningkatkan kemampuan penggunaan TIK & 3,9 & Sangat Baik \\
\hline & Skor rerata total & 15 & \\
\hline & Skor rerata maksimal & 16 & \\
\hline
\end{tabular}

Berdasarkan Tabel 2 didapatkan bahwa para siswa memberikan respon yang sangat baik terhadap penggunaan facebook sebagai media pembelajaran, dengan tingkat dukungan $15 / 16=94 \%$ atau kategori sangat baik. Hal tersebut menunjukkan bahwa para siswa dapat menerima dan mendukung pembelajaran menggunakan facebook. Ketertarikan siswa menggunakan facebook dapat berpotensi memotivasi siswa mempelajari suatu topik pelajaran sehingga memungkinkan guru mengintegrasikan pelajaran tersebut kedalamnya. Hal tersebut dapat memperlancar proses pembelajaran karena dapat terbangun komunikasi antar kelompok siswa dan antara siswa dengan guru (Calvo, Arbiol \& Iglesias, 2014). Dibalik kelebihan Facebook juga terdapat kelemahan yang salah satunya adalah penggunaannya sulit dikontrol, sehingga siswa dapat terlalu asyik dengan sesuatu yang tidak penting di luar konteks pelajaran 
dan mengabaikan tugas yang seharusnya diselesaikan. Kebanyakan facebook hanya digunakan sekedar bersenang-senang, berkomunikasi dengan teman, atau sekedar ajang narsis-narsisan, sehingga tidak salah kalua banyak pihak memandang facebook secara negatif. Walaupun demikian facebook tetap memiliki manfaat lebih banyak ketimbang mudharatnya ketika kita dapat memanfaatkan potensi yang dimilikinya secara maksimal. Salah satu kelebihannya adalah facebook dapat digunakan untuk menciptakan lebih banyak komunikasi antar guru dan siswa (Bowers \& Campbell, 2008). Dampak negatif muncul jika kita tidak dapat menggunakan teknologi sebagaimana mestinya.

\section{SIMPULAN DAN SARAN}

Dari kegiatan pengabdian kepada masyarakat (PKM) "Penggunaan facebook sebagai media inovatif dalam pembelajaran SMP dan SMA di Perguruan Muhammadiyah Wiyung Surabaya" dapat ditarik kesimpulan bahwa melalui pelatihan (training), pendampingan (mentoring), penerapan (implementation), dan penilaian (evaluation), penggunaan facebook sebagai media pembelajaran inovatif dapat diperoleh peningkatan pemahaman guru, menghasilkan media pembelajarn inovatif karya guru, dan mendapatkan respon yang baik dari siswa.

Kegiatan ini hendaknya dapat ditindaklanjuti oleh pihak pimpinan Perguruan Muhammadiyah Wiyung Surabaya dan sekolah-sekolah yang dikelolanya (SMP Muhammadiyah 17 Surabaya, dan SMA Muhammadiyah 9 Surabaya) dengan mengembangkan pembelajaran yang berbasis teknologi informasi dan komunikasi lainnya. Di samping itu juga perlu dilakukan secara berkala workshop pengembangan pembelajaran yang berbasis teknologi informasi dan komunikasi lainnya yang dapat memacu para guru untuk mengembangkan pembelajaran yang aktif, inovatif, kreatif. efektif, dan menyenangkan.

\section{DAFTAR PUSTAKA}

Bere A, 2012. A comparative study of student experiences of ubiquitous learning via mobile devices and learner management systems at a South African university. Proceedings of the 14th Annual Conference on World Wide Web Applications; Durban.
Bowers, Campbell J, 2008. Cyber "pokes": Motivational antidote for developmental college readers. Journal of College Reading and Learnin Vol 39 No $1 \mathrm{p} 74$ 87.

Calvo R, Arbiol A, Iglesias A, 2014. Are all chats suitable for learning purposes? A study of the required characteristics. Procedia Computer Science Vol $27 \mathrm{p}$ 251-260.

Facebook 2011 Facebook press room: Statistics Retrieved from http://www.facebook.com/ press/info.php?statistics.

Fewkes A M, McCabe M, 2012. Facebook: Learning Tool or Distraction? Journal of Digital Leraning in Teacher Education Vol 28 No 3 p 92-98.

Hartono B, 2004. Pemanfaatan TIK dalam Pembelajaran. Tersedia pada http://www. bebeasli.com. Diakses pada tanggal 27 April 2012.

Kustijono R, 2012. Pembelajaran melalui Facebook Yang Melatihkan Keterampilan Proses Sains Dasar Dalam Mata Kuliah media Pembelajaran. Seminar Nasional Pendidikan Sains oleh Prodi Pendidikan Sains Unesa Tanggal 15 Desember 2012. Prosiding, ISBN: 0217146-1-4.

Kustijono R, 2013. Melatih Keterampilan Berpikir Kritis Melalui Facebook Dalam Mata Kuliah Multimedia Pada Mahasiswa Fisika, Seminar Nasional Sains Oleh Program Pascasarjana Unesa Tanggal 19 Januari 2013. Prosiding, ISBN: 978-602-7508-55-2.

Mayer RE, 2001. Multimedia Learning. USA: Cambride University press.

Ni'am M, Kustijono R, 2013. Pengembangan Pembelajaran SMP Melalui Facebook Pada Materi Alat Optik. Jurnal Inovasi Pendidikan Fisika Vol 02 No 022013.

Nurtjahjawilasa, 2004. Efektifitas Multimedia dalam Menunjang Pembelajaran Peserta Diklat. Seminar Nasional Teknologi Pembelajaran, Depdiknas, Jakarta: 1-2 Desember 2004.

Payong MR, 2012. Beberapa Masalah dalam Pembelajaran Multimedia. Tersedia pada http://www.sinarharapan.co.id. Diakses pada tanggal 8 April 2012.

Rusman, 2012. Komputer Sebagai Media Pembelajaran. Tersedia pada http://www.geocities.com. Diakses pada tanggal 8 April 2012. 
Rudy K., dkk., Penggunaan Facebook sebagai ...

Samsudin A., 2010. Peran Multimedia Interaktif (MMI) dalam Pembelajaran Fisika. Tersedia pada http://www.pendidikansains.blogspot.co



Siswanto, 2012. Minat Guru Pada Multimedia Pembelajaran. Tersedia pada http://www.komed.org. Diakses pada tanggal 8 April 2012. 